\title{
Aptamers as Tools in Molecular Biology and Immunology
}

M. FAMUlOK ${ }^{1}$ and G. MAYER ${ }^{2}$

1 Introduction. . . . . . . . . . . . . . . . . . . . . . . . 123

2 Aptamers for Antibodies . . . . . . . . . . . . . . . . . . . . . . . . . . . 125

3 The Interruption of Lymphocyte Signal Transduction Pathways by Aptamers . . . . . . . 125

4 Growth Factors as Target Proteins for In Vitro Selection . . . . . . . . . . . . . . 127

5 Anti-viral Aptamers . . . . . . . . . . . . . . . . . . . . . . . . . . . . . 129

6 Specific Aptamers with High Affinity Inhibit Enzyme Function . . . . . . . . . . . . 129

7 Aptamers Against Various Target Molecules . . . . . . . . . . . . . . . . . . 131

8 Summary . . . . . . . . . . . . . . . . . . . . . . . . . . . 133

References . . . . . . . . . . . . . . . . . . . . . 134

\section{Introduction}

In 1990 TUERK and Gold introduced the first RNA aptamer for bacteriophage T4 DNA polymerase, obtained by a new combinatorial technique which they designated as SELEX (systematic evolution of ligands by exponential enrichment). In parallel, Ellington and Szostak (1990) showed that it is also possible to select RNA aptamers which are able to specifically complex organic molecules of low molecular weight, thus serving as receptor molecules based on nucleic acids rather than proteins. Since then, considerable progress has been achieved in the field of in vitro selection of combinatorial nucleic acid libraries, which demonstrates its impressive potential as a tool in molecular biology, diagnostics, molecular medicine, drug discovery, and bio-organic chemistry. Today, the SELEX process has been applied to more than a hundred different target molecules, and aptamers are known for almost every kind of targets such as organic dyes, amino acids, biological cofactors, antibiotics, peptides and proteins or even whole viruses (BELL et al. 1998; Gal et al. 1998; Ellington and Osborne 1997; Kraus et al. 1998; YANG et al. 1998; EATON 1997; PAN et al. 1995), showing that aptamers can be obtained for almost any desired target whether complex or small.

\footnotetext{
${ }^{1}$ Kekule-Institut für Organische Chemie and Biochemie, Gerhard-Domagk-Str. 1, D-53121 Bonn, Germany

2 Institut für Biochemie der LMU München, Feodor-Lynen-Str. 25, D-81377 Munich, Germany
} 
The isolation of specific antagonists for proteins which are involved in disease processes is one of the major goals in pharmacological research. Drug discovery has been greatly facilitated by computer-assisted drug design and various screening strategies of diverse combinatorial libraries of small molecules, peptides, Fab fragments, and antibodies. The SELEX technology provides a powerful method for the screening of large libraries of oligonucleotides, with diversities of up to $10^{15}$ different molecules, for specific ligand-binding nucleic acids which in many cases have been shown to not only bind a certain target protein, but also to inhibit its biological function. Many isolated aptamers are aimed at possible therapeutic and/or diagnostic applications. Insufficient stability, often cited as the major potential drawback of nucleic acids as therapeutic agents, can easily be overcome by using libraries of chemically modified nucleic acids, such as $2^{\prime}$-fluoro- or $2^{\prime}$-amino-2'-deoxypyrimidine containing nucleic acids. Modifications of that kind have been shown to be compatible with the enzymatic steps of the SELEX process. Other strategies which circumvent the stability problem of RNA or DNA include the so-called mirrorimage, or Spiegelmer, approach by exploiting nuclease resistance of the enantiomer of naturally occurring nucleic acids (KLUBMANN et al. 1996; Nulte et al. 1996).

Various recent examples illustrate the potential of aptamers in affecting cellular processes. In this review we will give an overview on recent progress in oligonucleotide selections and applications of aptamers as potential tools in drug discovery, diagnostics, molecular medicine, and for the dissection of cellular processes of immunological relevance (Table 1).

Table 1. Summary of the targeted molecules/viruses used for SELEX experiments

\begin{tabular}{|c|c|c|c|}
\hline Target molecule & $\begin{array}{l}\text { Dissociation } \\
\text { constant (nM) }\end{array}$ & $\begin{array}{l}\text { Possible therapeutic and/or } \\
\text { diagnostic application }\end{array}$ & Reference \\
\hline $\operatorname{IgE}$ & 10.0 & Allergic disease & WIEGAND et al. (1996) \\
\hline $\begin{array}{l}\text { Anti-acetylcholine } \\
\text { autoantibodies }\end{array}$ & 60.0 & Myasthenia gravis & LeE and Sullenger (1997) \\
\hline IFN- $\gamma$ & 6.8 & $\begin{array}{l}\text { Inflammation and immune } \\
\text { response }\end{array}$ & KuBIK et al. (1997) \\
\hline L-selectin & 3.0 & Inflammation & O'CoNNELl et al. (1996) \\
\hline CD4 & $\mathrm{N} / \mathrm{A}$ & Immune response & Kraus et al. (1998) \\
\hline bFGF & 0.350 & Angiogenesis & JELLINEK et al. (1993) \\
\hline $\mathrm{KGF}$ & 0.0003 & $\begin{array}{l}\text { Epithelial hyperproliferative } \\
\text { disease }\end{array}$ & PAGRATIS et al. (1997) \\
\hline PDGF & 0.1 & Tumor development & GrEEN et al. (1996) \\
\hline VEGF & 0.14 & Neovascularization & GrEEN et al. (1995) \\
\hline RSV & 40.0 & Viral infection & PAN et al. (1995) \\
\hline HIV-1 RT & 1.0 & Viral replication & $\begin{array}{l}\text { TUERK et al. (1992) } \\
\text { SCHNEIDER et al. (1995) }\end{array}$ \\
\hline HIV-1 integrase & 10.0 & Viral replication & ALLEN et al. (1995) \\
\hline HIV-1 rev & $\mathrm{N} / \mathrm{A}$ & Viral replication & GIVER et al. (1993) \\
\hline$\alpha$-thrombin & 25.0 & Thrombosis & $\begin{array}{l}\text { Bock et al. (1992), KuBIK et al } \\
\text { (1994), LATHAM et al. (1994 }\end{array}$ \\
\hline Activated protein $\mathrm{C}$ & 110.0 & Thrombosis & GAL et al. (1998) \\
\hline $\mathrm{hNE}$ & N/A & Inflammation & Charlton et al. (1997) \\
\hline PTPase & 18.0 & $\begin{array}{l}\text { Oncogenesis, viral and } \\
\text { cellular regulation }\end{array}$ & BeLl et al. (1998) \\
\hline $\mathrm{PLA}_{2}$ & 118.0 & ARDS, Septic shock & BRIDONNEAU et al. (1998) \\
\hline
\end{tabular}




\section{Aptamers for Antibodies}

IgE antibodies play a key role in allergic responses. Aptamer antagonists, singlestranded DNA and 2'-amino-modified RNA molecules which bind human IgE have been isolated by in vitro selection (WIEGAND et al. 1996). Truncated aptamers (designated as IGEL1.2 -2'-amino RNA- and D17.4 -ssDNA-) were shown to competitively inhibit the interaction of human IgE with its FceRI receptor in rat basophilic leukemia cells transfected with the human IgE receptor. The oligonucleotides block the IgE-mediated release of biogenic amines, such as serotonin, which are important mediators in allergic responses. Because of these properties the selected aptamers may have the potential to serve as a class of new therapeutics for the therapy of allergic diseases.

An aptamer directed against the antibody which plays a decisive role during the development of the autoimmune disease myasthenia gravis was shown to serve as a decoy RNA molecule (LeE and SulLENGER 1997). Myasthenia gravis is a muscular disease which results in progressive muscle weakness. This effect is based on the binding of anti-receptor autoantibodies to acetylcholine receptors in the motor end plate of neuromuscular junctions, affecting failure of muscle response to neuronal impulses (LindSTROM et al. 1988). The selected aptamer, modified by substitution of the $2^{\prime}-\mathrm{OH}$ for a $2^{\prime}-\mathrm{NH}_{2}$-group at the riboses of pyrimidine residues to improve its resistance against degradation by nucleases, recognizes anti-acetylcholine receptor autoantibodies present in the serum of patients that suffer from myasthenia gravis. Additionally they inhibit the binding of acetylcholine receptors to the autoantibodies. In this way, the undesired antibody-mediated immune response could be inhibited.

DoudNA et al. (1995) isolated RNA sequences that mimicked a major autoantigenic epitope of the human insulin receptor. The goal of this approach was to obtain an aptamer which could be used in the treatment of patients with extreme insulin resistance type B. The selection was performed with an anti-human insulin receptor mouse monoclonal antibody (designated as MA20) which recognizes the same epitope of the insulin receptor-like autoantibodies present in the sera of these patients. The selected aptamers showed cross-reactivity with the autoantibodies and were shown to serve as RNA decoys, with the effect that they protected the insulin receptor from antibody binding.

\section{The Interruption of Lymphocyte Signal Transduction Pathways by Aptamers}

Aptamers targeted against proteins which are involved in inflammatory processes are of considerable medical interest. Interferon $\gamma(\mathrm{IFN}-\gamma)$ is an immunoregulatory cytokine which is synthesized and secreted by Th1 and NK cells (TRINCHIERI and 
Perussia 1985). It is thought to participate in nearly all phases of immune and inflammatory responses (FARRAR and SCHREIBER 1993). IFN- $\gamma$ plays crucial roles in promoting inflammatory responses by stimulating macrophage cytotoxicity, enhancing adhesion of vascular endothelial cells, and facilitating lymphocyte extravasation. KUBIK et al. (1997) isolated RNA aptamers which bind to IFN- $\gamma$ with high affinity and specificity. Furthermore, the aptamer inhibits IFN- $\gamma$-induced expression of MHC class I and ICAM-1, important proteins in the genesis of inflammatory disease, by human myeloid leukemia cells. The regulation of IFN- $\gamma$ activity by specific ligands which inhibit the binding of IFN- $\gamma$ to its receptors may have an important potential for therapeutic applications. This aptamer might be of interest for diagnostic purposes as well.

LEE et al. (1996) reported that several synthetic oligonucleotides can block IFN- $\gamma$ mediated effects in human cell cultures. Originally these oligonucleotides were designed as antisense-molecules to form a triple helix with the $\mathrm{X}-\mathrm{X}_{2}$ box region of the HLA-DR $\alpha$ gene promoter. Because the oligonucleotide is able to inhibit IFN- $\gamma$ induced up-regulation of MHC class I and II and ICAM-1 expression, LEE et al. (1996) suggested a mechanism similar to that of aptamers for the inhibitory function of the synthetic oligonucleotide, by dissecting the signal transduction pathway through IFN- $\gamma$ binding. This is an impressive example for a possible application of an oligonucleotide as an inhibitory drug in medicinal chemistry, in this case for inhibition of undesired immune responses after transplantation.

Many cell-cell interactions in the vascular system are regulated by selectins, a family of cell adhesion molecules subdivided into L-selectin, P-selectin, and E-selectin. Selectins are involved in early steps of tissue injury following hypoxemia, reperfusion, or inflammation (Bevilacqua and Nelson 1993; Bevilacqua et al. 1994). Various ligands are known, the most prominent one being silalyl Lewis ${ }^{\mathrm{x}}$, that block the interaction of L-selectin with other cell surface receptors, such as glycosylation-dependent cell adhesion molecule-1 (GlyCAM-1), but none of these ligands is able to discriminate between the three selectin isoforms. The SELEX technology was used to isolate oligonucleotide ligands for L-selectin (O'CONNELL et al. 1996). Nuclease stabilization was achieved by using a $2^{\prime}$-amino-2'-deoxypyrimidine containing oligonucleotide library. The isolated aptamer was shown to bind L-selectin with high affinity and specificity in a calcium-dependent manner and to selectively discriminate between the three selectin isoforms. Furthermore, the aptamer was able to recognize the native protein on cell surfaces.

Another example of aptamers directed against an immunologically relevant target are RNA molecules selected to bind to the CD4 protein. The CD4 antigen interacts with MHC class II on antigen presenting cells (APCs) and plays an essential part in HIV-1 infection (DAGLEISH et al. 1984). In previous studies it was shown that antibodies directed against CD4 can block both MHC II and HIV-1 complex formation. Using a library of $2^{\prime}$-fluoro modified RNAs, randomized at 36 positions Kraus et al. (1998), isolated aptamers which bind CD4. These aptamers were able to inhibit mixed lymphocyte reactions nearly as well as Fab fragments or IgG antibodies, which may lead to a possible application targeted to manipulations of the immune system. 


\section{Growth Factors as Target Proteins for In Vitro Selection}

Growth factors play an important role in cell proliferation, cell migration, tissue remodeling, and wound healing (FolKMAN and KLAGSBRUN 1987; GosPoDARowitz 1991). Angiogenesis, the development of new blood vessels, is often associated with pathological processes such as cancer development and metastasis. For that reason, there is great interest in obtaining antagonists that inhibit growth factor functions. In the following, we give an overview of nuclease-resistant aptamers that have been isolated by in vitro selection for binding to a variety of growth factors, such as basic fibroblast growth factor (bFGF), human keratinocyte growth factor (hKGF), platelet derived growth factor (PDGF), and vascular endothelial growth factor (VEGF).

JELLINEK et al. (1995) reported the isolation of $2^{\prime}$-amino-modified RNA inhibitors of bFGF. This growth factor initiates angiogenesis by binding to either heparin proteoglycans (low-affinity site) or tyrosine kinase receptors (high-affinity site) on the surfaces of endothelial cells (Moscatelli 1987). Overexpression of bFGF is correlated with many malignant disorders. The selected aptamer was extensively characterized, and it could be shown that a minimal aptamer, designated as M21A, is sufficient for binding to bFGF, with a dissociation constant of $350 \mathrm{pM}$. M21A inhibits the binding of bFGF to low-affinity sites on CHO cells with an $\mathrm{ED}_{50}$ of $1 \mathrm{nM}$ and the binding to high-affinity sites with an $\mathrm{ED}_{50}$ of $3 \mathrm{nM}$. The bFGF-dependent migration of bovine aortic endothelial cells (BAEs) is inhibited by the aptamer M21A in a dose-dependent manner.

PAgratis et al. (1997) selected 2'-amino- and 2'-fluoro-2'-deoxyribonucleotidemodified RNA inhibitors for hKGF. KGF, a member of the FGF family (FINCH et al. 1989), is a basic heparin binding growth factor for epithelial cells (RUBIN et al. 1989). By overexpression of hKGF it was shown that this growth factor participates in diseases like psoriasis and dermatoses with psoriasiform hyperplasia (StAiAno-Coico et al. 1993), inflammatory bowel disease (BrAUCHLE et al. 1996; FINCH et al. 1996), and neoplasia (IsHIL et al. 1994). The isolated hKGF aptamer antagonists bind hKGF with a dissociation constant of up to $0.3 \mathrm{pM}$, which is the tightest binding aptamer reported so far. Compared with the $2^{\prime}$ amino-modified oligonucleotide ligands, the obtained $2^{\prime}$-fluoro-modified RNA ligands showed higher affinities and bioactivities. The aptamers can competitively inhibit hKGF binding to its receptor and inhibits mitogenic activity with $\mathrm{k}_{\mathrm{i}}$ values of $92 \mathrm{pM}$. Thus, these nuclease-resistant molecules may be useful for the development of novel pharmaceutical lead compounds for epithelial hyperproliferative disease.

Tumor cell lines produce and secrete PDGF. Therefore, autocrine as well as paracrine effects on tumor stroma and tumor growth can be imagined. Besides the impact of PDGF on tumor development, this growth factor also participates in other proliferative disorders such as glomerulonephritis (IIDA et al. 1991) and arteriosclerosis (LINDNER et al. 1995; LINDNER and REIDY 1995). SELEX-derived ssDNA selected for specific complexing with PDGF showed an 
inhibition of PDGF function (GREEN et al. 1996). The minimal PDGF binding motifs of the selected aptamers inhibit PDGF interaction with its a- and b-receptors and even specifically inhibit mitogenic effects of PDGF. All isolated aptamers interfered with the PDGF-BB and PDGF-AB isoforms but not with the PDGF-AA isoform, indicating that the interaction is site-specific for the PDGF B-chain.

The aptamer for vascular permeability factor/vascular endothelial growth factor (VPF/VEGF) provides an excellent and very intriguing example for postSELEX modifications of 2'-aminopyrimidine-modified RNA aptamers (GREEN et al. 1995) (Fig. 1). The isolated high affinity RNA aptamers, which contained the 2 -amino-2'-deoxy modifications only at the pyrimidine nucleotides, could be reduced to a 24 nucleotide minimal motif that is sufficient for VPF/VEGF binding. The minimal aptamer contains 14 ribopurines, and the substitution of ten of them by 2'-O-methyl purine derivatives improved the binding affinity 17 -fold and increased the half life up to $t_{1 / 2}=131 \mathrm{~h}$. The $2^{\prime}$-ribose-positions that would tolerate a substitution by the $2^{\prime}$-methoxy group were defined by synthesizing the minimal oligonucleotide from $2: 1$ mixtures of phosphoramidite derivatives of natural purines (RNA-purines) and unnatural $2^{\prime}$-methoxy-2'-deoxy purines. Re-selection of the resulting library of variants of the originally selected aptamer allowed the separation of aptamer variants that showed decreased affinity to VPF/VEGF, as a result of the substitution of some $2^{\prime}-\mathrm{OH}$-purine residues for $2^{\prime}-\mathrm{OCH}_{3}$-purines from those in which this substitution improved the aptamer binding affinity. These positions were then identified by digestion of radiolabeled modified aptamers at high $\mathrm{pH}$. Under these conditions, selective hydrolysis of the RNA is observed only at the remaining $2^{\prime}-\mathrm{OH}$, but not at the $2^{\prime}$-methoxy residues.

The minimal modified aptamer is currently in clinical trials to prove its ability to inhibit angiogenesis and neovascularization, which contributes to the pathology of many angiogenesis-associated diseases.

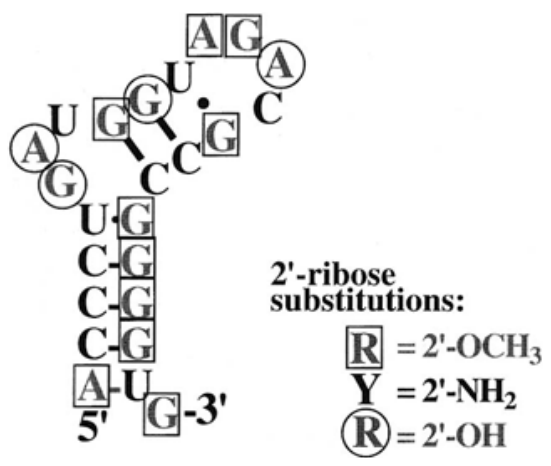

Fig. 1. The minimal VEGF aptamer. The post-SELEX modifications of purine bases are highlighted in green. (From GreEN et al. 1995) 


\section{Anti-viral Aptamers}

Aptamers deliver potential tools for dissecting the life cycle of viruses by interacting with proteins essential for viral replication. For human immunodeficiency virus-1 (HIV-1) and Rous sarcoma virus (RSV), oligonucleotides have been isolated that can efficiently interrupt essential steps in the viral life cycle, opening up the potential of treating viral diseases with aptamers.

PAN et al. (1995) selected RNA molecules that neutralize RSV in a concentration-dependent manner. These RNAs were selected by incubation of the random RNA library with whole RSV particles and subsequent separation of the non-virus bound aptamers from those that remained immobilized on the surface of the virus particles. Consequently, the isolated aptamers were shown to interact with the virus surface, unable to enter the virus itself. In a virus-neutralizing activity assay the yield of viral protein could be reduced to $85 \%-92 \%$ at RNA concentrations of 20.0nM. Virus replication was completely blocked at an aptamer concentration of $160.0 \mathrm{nM}$. It was assumed that the presence of the virus-specific aptamers resulted in conformational changes of the glycoprotein structures of viral coat proteins, thereby interfering with the attachment of viruses to the targeted cell and with cellmembrane fusion. Substitution of the pyrimidines with $2^{\prime}$-fluoro-2'-deoxypyrimidine derivatives increased the stability against nucleases but led to a significant decrease in virus neutralization properties.

Various proteins of HIV-1 which are essential for virus replication have been chosen as targets for isolating specific oligonucleotide antagonists. Allen et al. (1995) selected RNA aptamers directed against HIV-1 integrase. TuERK et al. (1992) and SCHNEIDER et al. (1995) isolated RNA and ssDNA aptamers which recognize HIV-1 reverse transcriptase (HIV-1 RT). The isolated aptamers were able to inhibit the DNA polymerase activity of HIV-1 RT, with values of $\mathrm{K}_{\mathrm{i}}$ as low as $0.3 \mathrm{nM}$ (ssDNA aptamer). In addition, the aptamers selectively discriminated between various RTs, showing high affinity and specificity for HIV-1 RT whereas they did not bind to AMV RT or MMLV RT. GIVER et al. (1993) used the HIV-1 rev protein as a target for aptamer selections. Symensma et al. (1996) showed that RNA aptamers, derived against the HIV-1 Rev protein, can mediate Rev function in vivo. This is an impressive example that describes the in vivo functionality of a RNA aptamer.

\section{Specific Aptamers with High Affinity Inhibit Enzyme Function}

One of the first ssDNA aptamers was directed against human $\alpha$-thrombin, and ssDNA (Bock et al. 1992), RNA (KuBIK et al. 1994) as well as $2^{\prime}$ modified RNA aptamers (LATHAM et al. 1994) are known for human $\alpha$-thrombin. BocK et al. (1992) isolated ssDNA molecules that bind human thrombin and inhibited blood clotting in vitro. They showed that the thrombin-dependent blood clotting activity was blocked up to $50 \%$ at an aptamer concentration of $25 \mathrm{nM}$. KUBIK et al. (1994) 
selected RNA- and modified RNA aptamers for the same target. For all of these oligonucleotides, mapping of the binding site suggested that they bound to the heparin-binding exo site. The biological role that $\alpha$-thrombin plays in mechanisms of blood clotting indicates a potential medical application. Indeed, the selected aptamers show inhibitory function of this process in vitro and potential applications as anticoagulants in an ex vivo, whole artery angioplasty model and in preclinical studies with dogs (LI et al. 1994; DEAudA et al. 1994).

GAL et al. (1998) selected RNA ligands that inhibit activated protein C (APC) function, an essential protein in thrombosis and hemostasis regulation. The activation of protein $\mathrm{C}$ is induced by thrombin complexed to thrombomodulin (ESMON and OwEN 1981). GAL et al. showed that the selected aptamer, designated as APC99, inhibits APC function with a $\mathrm{k}_{\mathrm{i}}$ of $137 \mathrm{nM}$ and do not interact with related serine-proteases like thrombin, human neutrophil elastase, or hepatitis C virus NS3 protease.

Human neutrophil elastase (hNE) plays a crucial role in several inflammatory diseases, such as septic shock, myocardial ischemia-reperfusion injury, emphysema, and especially in acute respiratory distress syndrome (ARDS) (DoRING 1994; REPINE 1992). Inhibitors for proteases are well known but they generally react unspecifically with the active site (Edwards and Bernstein 1994). Valyl phosphonate is an unspecific and irreversible inhibitor for serine proteases (OLEKSYSZYN and Powers 1991). To aim towards a specific interaction with one particular protease, this small molecule was covalently attached to every pool member of a randomized ssDNA library. This selection method, designated as blended-SELEX (Gold et al. 1995), was used to isolate specific RNA (SMITH et al. 1995) as well as ssDNA (ChARLTon et al. 1997) inhibitors of hNE. The aptamers that best promoted the covalent reaction of the reactive moiety inactivated elastase with a $\mathrm{k}_{\mathrm{obs}}$ around $2 \times 10^{8} \mathrm{M}^{-1}$ per min, almost two orders of magnitude faster than peptidebased inhibitors. In a parallel study, the aptamer inhibitor was also shown to reduce lung injury in a rat alveolitis model (BLEss et al. 1997). By using the ${ }^{99 \mathrm{~m}} \mathrm{Tc}$ labeled anti elastase aptamer and, as a control, a ${ }^{99 \mathrm{~m}}$ Tc-labeled rat anti-elastase $\mathrm{IgG}$, which is clinically used during in vivo imaging of inflammatory sites, it was shown that the aptamer achieved a significantly higher target-to-background (T/B) ratio in less time than the IgG (Fig. 2).

This example indicates that in some cases specific ligand binding nucleic acids might be advantageous over antibodies; in the present case the superior $\mathrm{T} / \mathrm{B}$ ratios were attributed to the more rapid clearance of the aptamer from the peripheral circulation compared to the IgG.

High concentrations of human nonpancreatic secretory phospholipase $A_{2}$ (hnsp-PLA $_{2}$ ) are associated with various diseases such as acute pancreatitis, ARDS, bacterial peritonitis, and septic shock (RinTAla and Nevalainen 1993). Antagonists with high affinity and specificity are proposed to block the biological role of phospholipase $\mathrm{A}_{2}\left(\mathrm{PLA}_{2}\right)$. One such antagonist is LY311727, a small molecule indol-based inhibitor of PLA 2 (Schevitz et al. 1995). BRIDONNEAU et al. (1998) have chosen a SELEX approach for new drug design and isolated $2^{\prime}$-amino-modified RNA aptamers as $\mathrm{PLA}_{2}$ antagonists. One of these ligands, designated as 
a



b

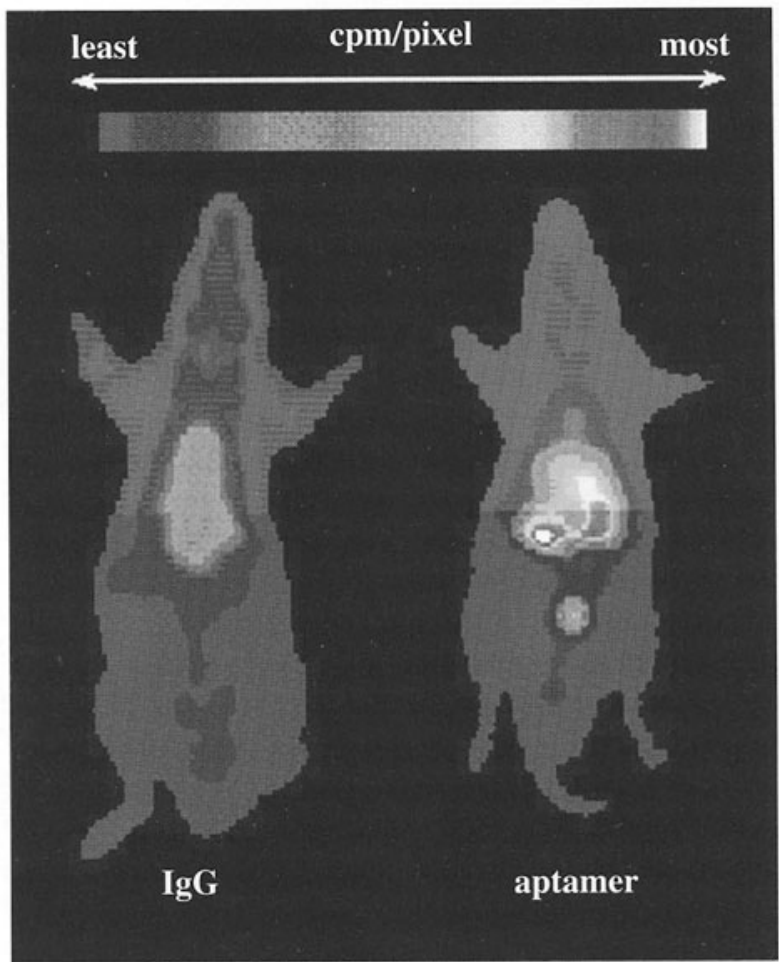

Fig. 2a,b. In vivo imaging with an aptamer. a DNA aptamer that binds to neutrophil elastase and acts as an irreversible inhibitor via the attached valine derivative. b Inflammation imaging by aptamer NX21909 (right) and IgG (left) after10 min; cpm, counts per minute. (From CHARLTON et al. 1997)

aptamer 5 , showed a $\mathrm{k}_{\mathrm{i}}$ of $0.14 \mathrm{nM}$ and $93 \%$ inhibition in the chromogenic hnps$\mathrm{PLA}_{2}$ enzymatic activity assay (REYNOLDs et al. 1992). In tissue-based contraction assays, the truncated version of aptamer 5 showed higher apparent dissociation constants $\left(\mathrm{k}_{\mathrm{B}}=118 \pm 26 \mathrm{nM}\right)$ than the non-oligonucleotide based antagonist LY311727 (270 $\pm 50 \mathrm{nM})($ SNYDER et al. 1993). 
Protein tyrosine phosphatases (PTPases) play important roles in oncogenesis, pathogenesis and the regulation of cellular and viral replication. Common antagonists show little specificity and cannot discriminate between various PTPases. Two different random pools, varying in length, have been exploited to isolate more specific ligands that bind and inhibit the PTPase active site (Bell et al. 1998). The selected aptamers shared a 21-residue conserved sequence independent of the pool they were isolated from and were shown to inhibit the Yersinia PTPase used in the selection protocol by $\mathrm{IC}_{50}$ values of 10.0 and $35.0 \mathrm{nM}$.

\section{Aptamers Against Various Target Molecules}

An impressive example for the application of combinatorial RNA libraries to identify natural RNA binding sites for a given target protein was provided by BuCKANOVICH and DARNELl 1997. They selected RNA aptamers which bind to the neuron-specific RNA binding protein Nova-1, an autoantigen in a neurologic disorder associated with breast cancer and dysfunction of brainstem or spinal motor systems (BuCKANOvicH et al. 1996). Although it was known that Nova-1 contained three RNA binding domains, a particular RNA motif recognized by Nova-1 was unknown. To identify such motifs, an in vitro selection for Nova-1 binders was performed using a library of $10^{15}$ different 52-mer RNAs. Isolated aptamers contained a conserved 15-mer consensus motif [UCAU(N) $\left.)_{0-2}\right]_{3}$ which was found to be absolutely necessary for Nova-1 binding. Remarkably, a GenBank search for this consensus sequence identified natural Nova-1 binding sites in two neuronal premRNAs. One sequence lies within an intron of the glycine receptor $\alpha 2$ (GlyR $\alpha 2$ ) pre-mRNA. The other sequence was the pre-mRNA which encodes for Nova-1 itself. Both natural pre-mRNAs specifically interact with authentic Nova-1 protein. These studies established that Nova-1 functions as a sequence-specific nuclear RNA binding protein in vivo. It was one of the first SELEX experiments that identified previously unknown, naturally occurring, nucleic acid binding sites of a RNA binding protein. The authors suggested that the mechanism of the neurologic disease involves disruption of Nova-1 binding to GlyR $\alpha 2$ pre-mRNA by the autoantibody.

Vasopressin is known as an important peptide hormone which regulates water balance in the body (NIELSEN et al. 1995). This peptide plays a key role in various states of disease including diabetes insipidus as well as hyponatremia and polydipsia in schizophrenic patients (Goldman et al. 1997). Williams et al. (1997) used the SELEX method to isolate L-ssDNA ligands to vasopressin. In their approach D-DNA ligands have been selected using D-vasopressin as a target molecule. The enantiomer of the winning D-ssDNA aptamer, designated as L-ssDNA aptamer, has been synthesized and its ability to bind L-vasopressin was demonstrated. Importantly, this approach led to enhanced nuclease stability by mirror-image ssDNA (KLussmann et al. 1996; Nolte et al. 1996). The L-ssDNA-aptamer inhibited cAMP release mediated by vasopressin, but the cAMP release induced by oxytocin was not affected. 
Human thyroid stimulating hormone (hTSH) belongs to a family of glycohormone proteins such as leutinizing hormone $(\mathrm{hLH})$, follicle stimulating hormone (hFSH), and chorionic-gonadotropin (hCG) (PIERCE and PARsons 1981). The measurement of serum hTSH levels, secreted by the pituitary gland, is important for diagnosis of pituitary and thyroid disorders such as hyperthyroidism and hypothyroidism (LABRIE 1990). LIN et al. (1996) isolated specific ligands for hTSH that do not interact with the other members of the same protein family. They showed that selected oligonucleotides could be used in diagnostic assays.

HALLER and SARNOW (1997) isolated RNA molecules that show a 1000-fold higher affinity for N-7 methylguanosine than for nonmethylated guanosines. A remarkable feature of the selected RNA is that binding to the $5^{\prime}$ terminal cap structure leads to the inhibition of cap-dependent processes such as mRNA translation initiation. The cap structure plays an important role in many different biological processes, e.g., pre-mRNA splicing, nuclear transport, and mRNA stabilization. Haller and Sarnow showed that the isolated aptamer R8-35 not only displaces human cytoplasmic cap-binding complex, but also inhibits the formation of human nuclear cap-binding protein complexes like CBP20 and CBP80. This aptamer is an impressive example for selective discrimination between two highly related molecules with only small structural differences. In the reported case, aptamers provide useful tools to investigate and understand biological processes in living cells.

Another example indicating that remarkably specific aptamers can be isolated by SELEX was reported by YANG et al. (1998), who selected DNA ligands that bind to cellobiose, the disaccharide of cellulose. The selected motifs are able to discriminate sugar epimers, anomers, and other disaccharides. Oligosaccharides play an important role in cellular adhesion, inflammation and molecular recognition. Commonly, antibodies are used for diagnostic purposes but they often cannot discriminate between various sugar tags of cell surface receptors.

\section{Summary}

We have listed and described recent promising developments in the field of aptamer research. The properties and the application potential of aptamers propose an exciting future for aptamers either in the clinic or as research tools for various purposes. We have reviewed exciting examples in which the SELEX technology was applied to obtain promising tools that may help to facilitate our understanding of biological processes and to interfere at distinct points in signal transduction cascades. High affinities and specificities of aptamer/target-interactions can now routinely be achieved. Furthermore, a wide spectrum of chemical modifications of nucleotides is known which greatly increase the stability of RNA molecules in biological materials, considerably enhancing their application potential. The aptamer technology shows that the combination of organic synthesis and molecular biology can contribute to interesting and promising new drug leads, which may 
very soon find their way into daily clinical practice or onto the laboratory benches of many researchers in the life sciences.

Acknowledgements. We thank D. Proske, A. Jenne and M. Blind for critical reading of the manuscript.

\section{References}

Allen P, Worland S, Gold L (1995) Isolation of high-affinity RNA ligands to HIV-1 integrase from a random pool. Virology 209:327-336

Bell SD, Denus JM, Dixon JE, Ellington AD (1998) RNA molecules that bind to and inhibit the active site of a tyrosine phosphatase. J Biol Chem 273:14309-14314

Bevilacqua MP, Nelson RM (1993) Selectins. J Clin Invest 91:379-387

Bevilacqua MP, Nelson RM, Mannori G, Cecconi O (1994) Endothelial-Leukocyte adhesion molecules in human disease. Annu Rev Med 45:361-378

Bless NM, Ward PA (1997) Protective effects of an aptamer inhibitor of neutrophil elastase in lung inflammatory injury. Curr Biol 7:877-880

Bock LC, Griffin LC, Latham JA, Vermaas EH, Toole JJ (1992) Selection of single-stranded DNA molecules that bind and inhibit human thrombin. Nature 355:564-566

Brauchle M, Madlener M, Wagner AD, Angermeyer K, Lauer U, Hofschneider PH (1996) Keratinocyte growth factor is highly overexpressed in inflammatory bowel disease. Am J Pathol 149:521-529

Bridonneau P, Chang YF, O'Connell D, Gill SC, Snyder DW, Johnson L, Goodson TJ, Herron DK, Parma DH (1998) High-affinity aptamers selectively inhibit human nonpancreatic secretory phospholipase $\mathrm{A}_{2}$ (hnsp-PLA $_{2}$ ). J Med Chem 41:778-786

Buckanovich RJ, Darnell RB (1997) The neuronal RNA binding protein NOVA-1 recognises specific RNA targets in vitro and in vivo. Mol Cell Biol 17:3194-3201

Buckanovich RJ, Yang YY, Darnell RB (1996) The onconeural antigen Nova-1 is a neuron-specific RNA binding protein, the activity of which is inhibited by paraneoplastic antibodies. J Neurosci 16 : 1114-1122

Charlton J, Kirschenheuter GP, Smith D (1997) Highly potent irreversible inhibitors of neutrophil elastase generated by selection from a randomized DNA-valine phosphonate library. Biochemistry 36:3018-3026

Charlton J, Sennello J, Smith D (1997) In vivo imaging of inflammation using an aptamer inhibitor of human neutrophil elastase. Chem Biol 4:809-816

Dagleish AG, Beverly PCL, Clapham PR, Crawford MF, Greaves MF, Weiss RA (1984) The CD4 (T4) antigen is an essential component of the receptor for the AIDS retrovirus. Nature 312:763

DeAnda JA, Coutre SE, Moon MR, Vial CM, Griffin LC, Law VS, Komeda M, Leung LLK, Miller DC (1994) Pilot study of the efficacy of a thrombin inhibitor for use during cardiopulmonary bypass. Ann Thorac Surg 58:344-350

Doring G (1994) The role of neutrophil elastase in chronic inflammation. Am J Respir Crit Care Med 150:114-117

Doudna JA, Cech TR, Sullenger BA (1995) Selection of an RNA molecule that mimics a major autoantigenic epitope of human insulin receptor. Proc Natl Acad Sci USA 92:2355-2359

Eaton BE (1997) The joys of in vitro selection: chemically dressing oligonucleotides to satiate protein targets. Curr Opin Chem Biol 1:10-16

Edwards P, Bernstein P (1994) Synthetic inhibitors of elastase. Med Res Rev 14:127-194

Ellington AD, Szostak JW (1990) In vitro selection of RNA molecules that bind specific ligands. Nature 346:818-822

Esmon CT, Owen WG (1981) Identification of an endothelial cell cofactor for thrombin-catalyzed activation of protein C. Proc Natl Acad Sci USA 78:2249-2252

Farrar MA, Schreiber RD (1993) The molecular cell biology of interferon- $\gamma$ and its receptors. Annu Rev Immunol 11:571

Finch PW, Pricolo V, Wu A, Finkelstein SD (1996) Increased expression of keratinocyte growth factor messenger RNA associated with inflammatory bowel disease. Gastroenterology 110:441-451

Finch PW, Rubin JS, Miki T, Ron D, Aaronson SA (1989) Human KGF is FGF-related with properties of a paracrine effector of epithelial cell growth. Science $244: 752-755$ 
Folkman J, Klagsbrun M (1987) Angiogenic factors. Science 235:442-447

Gal SW, Amontov S, Urvil PT, Vishnuvardhan D, Nishikawa F, Kumar PKR, Nishikawa S (1998) Selection of a RNA aptamer that binds to human activated protein $\mathrm{C}$ and inhibits its protease function. Eur J Biochem 252:553-562

Giver L, Bartel DP, Zapp ML, Green MR, Ellington AD (1993) Selection and design of high-affinity RNA ligands for HIV-1 Rev. Gene 137:19-24

Gold L, Polisky B, Uhlenbeck O, Yarus M (1995) Diversity of oligonucleotide functions. Annu rev Biochem 64:763-797

Goldman MB, Robertson GL, Luchins DJ, Hedecker D, Pandey GN (1997) Psychotic exacerbations and enhanced vasopressin secretion in schizophrenic patients with hyponatremia and polydipsia. Arch Gen Psychiatry 54:443-449

Gospodarowitz D (1991) Fibroblast growth factors: from genes to clinical applications. Cell Biol Rev 25:307-314

Green LS, Jellinek D, Bell C, Beebe LA, Feistner BD, Gill SC, Jucker FM, Janjic N (1995) Nucleaseresistant nucleic acid ligands to vascular permeability factor/vascular endothelial growth factor. Chemistry \& Biology 2:683-695

Green LS, Jellinek D, Jenison R, stman A, Heldin CH, Janjic N (1996) Inhibitory DNA ligands to platelet-derived growth factor B-chain. Biochemistry 35:14413-14424

Haller AA, Sarnow P (1997) In vitro selection of a 7-methyl-guanosine binding RNA that inhibits translation of capped mRNA molecules. Proc Natl Acad Sci USA 94:8521-8526

Iida H, Seifert R, Alpers CE, Gronwald RGK, Phillips PE, Pritzl P, Gordon K, Gown AM, Ross R, Bowen-Pope DF, Johnson RJ (1991) Platelet-derived growth factor (PDGF) and PDGF receptor are induced in mesangial proliferation nephritis in the rat. Proc Natl Acad Sci USA 88:6560-6564

Ishil H, Hattori Y, Itoh H, Kishi T, Yoshida T, Sakamoto H (1994) Preferential expression of the third immunoglobulin-like domain of $\mathrm{k}$-sam product provides keratinocyte growth factor-dependent growth in carcinoma cell lines. Cancer Res 54:518-522

Jellinek D, Green LS, Bell C, Lynott CK, Gill N, Vargeese C, Kirschenheuter G, McGee DP, Abesinghe P, Pieken WA, et al. (1995) Potent $2^{\prime}$-amino-2'-deoxypyrimidine RNA inhibitors of basic fibroblast growth factor. Biochemistry 34:11363-11372

Jellinek D, Lynott CK, Rifkin DB, Janjic N (1993) High-affinity RNA ligands to basic fibroblast growth factor inhibit receptor binding. Proc Natl Acad Sci USA 90:11227-11231

Klußmann S, Nolte A, Bald R, Erdmann VA, Fürste JP (1996) Mirror-image RNA that binds D-adenosine. Nat Biotechnol 14:1112-1115

Kraus E, James W, Barclay AN (1998) Cutting edge: Novel RNA ligands able to bind CD4 antigen and inhibit CD4 + T lymphocyte function. J Immunology 160:5209-5212

Kubik MF, Bell C, Fitzwater T, Watson SR, Tasset DM (1997) Isolation and characterization of $2^{\prime}$-fluoro-, $2^{\prime}$-amino-, and 2'-fluoro-/amino-modified RNA ligands to human IFN-gamma that inhibit receptor binding. J Immunol 159:259-267

Kubik MF, Stephens AW, Schneider D, Marlar RA, Tasset D (1994) High-affinity RNA ligands to human alpha-thrombin. Nucleic Acids Res 22:2619-2626

Labrie F (1990) Hormones from molecules to diseases, E. E. Baulieu and P. A. Kelly, eds. (New York, N.Y.: Herman Publisher).

Latham JA, Johnson R, Toole JJ (1994) The application of a modified nucleotide in aptamer selection: novel thrombin aptamers containing 5-(1-pentynyl)-2'-deoxyuridine. Nucleic Acids Res 22:2817-2822

Lee PP, Ramanathan M, Hunt CA, Garovoy MR (1996) An oligonucleotide blocks interferon-gamma signal transduction. Transplantation 62:1297-1301

Lee SW, Sullenger BA (1997) Isolation of a nuclease-resistant decoy RNA that can protect human acetylcholine receptors from myasthenic antibodies. Nature Biotechnology 15:41-45

Li WX, Kaplan AV, Grant GW, Toole JJ, Leung LLK (1994) A novel nucleotide-based thrombin inhibitor inhibits clot-bound thrombin and reduces arterial platelet thrombus formation. Blood 83:677-682

Lin Y, Nieuwlandt D, Magallanez A, Feistner B, Jayasena SD (1996) High-affinity and specific recognition of human thyroid stimulating hormone (hTSH) by in vitro selected 2'-amino-modified RNA. Nucleic Acid Research 24:3407-3414

Lindner V, Giachelli CM, Schwartz SM, Reidy MA (1995) A subpopulation of smooth muscle cells in injured rat arteries expresses platelet-derived growth factor-B chain mRNA. Circ Res 76:951-957

Lindner V, Reidy MA (1995) Platelet-Derived growth factor ligand and receptor expression by large vessel endothelium in vivo. Am J Pathol 146:1488-1497

Lindstrom J, Shelton D, Fujii Y (1988) Myasthenia gravis. Advances in Immunology 42:233-284 
Moscatelli D (1987) High and low affinity sites from basic fibroblast growth factor on cultured cells: absence of a role for low affinity binding in the stimulation of plasminogen activator production by bovine capillary endothelial cells. J Cell Physiol 131:123-130

Nielsen S, Chou CL, Marples D, Christensen EI, Kishore BK, Knepper MA (1995) Vasopressin increases water permeability of kidney collecting duct by inducing translocation of aquaporin-CD water channels to plasma membrane. Proc Natl Acad Sci USA 92:1013-1017

Nolte A, Klußmann S, Bald R, Erdmann VA, Fürste JP (1996) Mirror-design of L-oligonucleotide ligands binding to L-arginine. Nat Biotechnol 14:1116-1119

O’Connell D, Koenig A, Jennings S, Hicke B, Han HL, Fitzwater T, Chang YF, Varki N, Parma D, Varki A (1996) Calcium-dependent oligonucleotide antagonists specific for L-selectin. Proc Natl Acad Sci USA 93:5883-5887

Oleksyszyn J, Powers J (1991) Irreversible inhibition of serine proteases by peptide derivatives of (alphaaminoalkylphosphonate)diphenyl ester. Biochemistry 30:485-493

Osborne SE, Ellington AD (1997) Nucleic acid selection and the challenge of combinatorial chemistry. Chem Rev 97:349-370

Pagratis NC, Bell C, Chang Y-F, Jennings S, Fitzwater T, Jellinek D, Dang C (1997) Potent 2'-amino-, and 2 '-fluoro-2'-deoxyribonucleotide RNA inhibitors of keratinocyte growth factor. Nature Biotechnology 15:68-73

Pan W, Craven RC, Qiu Q, Wilson CB, Wills JW, Golovine S, Wang JF (1995) Isolation of virusneutralizing RNAs from a large pool of random sequences. Proc Natl Acad Sci USA 92:1150911513

Pierce JG, Parsons IF (1981) Glycoprotein hormones: structure and function. Annu Rev Biochem $50: 465-495$

Repine J (1992) Scientific perspectives on adult respiratory distress syndrome. Lancet 339:466-469

Reynolds RJ, Hughes LL, Denis EA (1992) Analysis of human synovial fluid phospholipase A2 on short chain phosphatidylcholine-mixed micelles: development of a spectrophotometric assay suitable for a microtiterplate reader. Anal Biochem 204:190-197

Rintala EM, Nevalainen TJ (1993) Group II phospholipase A2 in sera of febrile patients with microbiologically or clinically documented infections. Clin Infect Disease 17:864-870

Rubin JS, Osada H, Finch RW, Taylor WG, Rudikoff S, Aaronson SA (1989) Purification and characterization of a newly identified growth factor specific for epithelial cells. Proc Natl Acad Sci USA 86:802-806

Schevitz RW, Bach NJ, Carlson DG, Chirgadze NY, Clawson DK, Dillard RD, Draheim SE, Hartley LW, Jones ND, Mihelich ED, Olkowski JL, Snyder DW, Sommers C, Wery JP (1995) Structurebased design of the first potent and selective inhibitor of human non-pancreatic secretory phospholipase A2. Nature Struct Biol 2:458-465

Schneider DJ, Feigon J, Hostomsky Z, Gold L (1995) High-affinity ssDNA inhibitors of the reverse transcriptase of type 1 human immunodeficiency virus. Biochemistry 34:9599-9610

Smith D, Kirschenheuter GP, Charlton J, Guidot DM, Repine JE (1995) In vitro selection of RNA-based irreversible inhibitors of human neutrophil elastase. Chemistry \& Biology 2:741-750

Snyder DW, Sommers CD, Bobbitt JL, Mihelich ED (1993) characterization of the contractile effects of human recombinant non-pancreatic secretory phospholipase A2 and other PLA2 s on guinea pig lung pleural-strips. J Pharmacol Exp Ther 266:1147-1155

Staiano-Coico L, Krueger JG, Rubin JS, D'limi S, Vallat VP, Valentino L (1993) Human keratinocyte growth factor effect in a porcine model of epidermal wound healing. J Ex Med 178:865-878

Symensma TL, Giver L, Zapp M, Takle GB, Ellington AD (1996) RNA aptamers selected to bind human immunodeficiency virus type $1 \mathrm{Rev}$ in vitro are Rev responsive in vivo. $\mathrm{J}$ Virol 70:179-187

Trinchieri G, Perussia B (1985) Immune interferon: a pleiotropic lymphokine with multiple effects. Immunology Today 6:131

Tuerk C, Gold L (1990) Systematic evolution of ligands by exponential enrichment: RNA ligands to bacteriophage T4 DNA polymerase. Science 249:505-510

Tuerk C, MacDougal S, Gold L (1992) RNA pseudoknots that inhibit human immunodeficiency virus type 1 reverse transcriptase. Proc Natl Acad Sci USA 89:6988-6992

Wiegand TW, Williams PB, Dreskin SC, Jouvin MH, Kinet JP, Tasset D (1996) High-affinity oligonucleotide ligands to human IgE inhibit binding to Fc epsilon receptor I. J Immunol 157:221-230

Williams KP, Liu XH, Schumacher TN, Lin HY, Ausiello DA, Kim PS, Bartel DP (1997) Bioactive and nuclease-resistant L-DNA ligand of vasopressin. Proc Natl Acad Sci USA 94:11285-11290

Yang Q, Goldstein IJ, Mei HY, Engelke DR (1998) DNA ligands that bind tightly and selectively to cellobiose. Proc Natl Acad Sci USA 95:5462-5467 